\title{
MECHANISMS OF METABOLIC ADAPTATION AND OXIDATIVE STRESS IN HERPESVIRUS INFECTIONS
}

\section{Ye.B. Kasymova, 0.A. Bashkina, A.A. Zhidovinov}

Article history:

Received 25 March 2019

Received in revised form 1 April 2019

Accepted 4 April 2019

\section{Astrakhan State Medical University, Astrakhan, Russia}

The pathogenesis of a chronic course and the complications of herpesvirus infections remains poorly understood nowadays despite the extreme relevance, associated with the pandemic of these infections and the severe complications in the activation of its latent forms.

Recent research has found that redox processes and, primarily, processes of free radical oxidation mainly determine the stability of the homeostasis of a living organism. As a result of the disturbance of the activity of this system, toxic products accumulate, which is one of the reasons for the imbalance in the regulation of homeostasis, leading to serious metabolic disorders, changes in the immune status, hormonal disorders, deep disturbances in the detoxification system, etc. [1].

The activation of free radical oxidative reactions is the main pathogenetic factor of many diseases and pathological processes, including herpesvirus infections, accompanied by lesion of the biological barriers of cell membranes [2].

The features of herpesvirus infections allow us to consider them as diseases of the immune system, with the development of variety of immunopathological reactions, which create the conditions for genesis of prolonged endotoxicosis, aggression of proinflammatory cytokines and free radicals causing various complications.

In this connection, in evaluation of the severity of endotoxemia, the relevance of the study of its immunobiochemical component is widely recognized, because the development of endogenous intoxication is accompanied by metabolic disorders of varying severity. At the same time, in non-physiological concentrations, fluids and tissues accumulate intermediate and final products of normal and impaired metabolism.

Malonic dialdehyde is considered to be a universal marker, which represents the level of pathological metabolism, correlating with the main clinical laboratory prognostic criteria of metabolic disorders.

Malonic dialdehyde is a secondary product of free radical oxidation of lipids and proteins, interacts with the $\mathrm{N}$-terminal residues of amino acids, proteins and amino groups of phospholipids with the formation of conjugated fluorescent Schiff-type compounds [4]. The increase in malondialdehyde indicates excessive activation of free radical oxidation, the decrease indicates inhibition of lipid metabolism. Malonic dialdehyde is very toxic and chemically active, has a damaging effect associated with the lesion of the structural and functional state of biomembranes. Their utilization in the body occurs at a very low rate, and as a result they accumulate, being a ballast that disrupts the functional state of cell biomembranes.

The rate of free radical oxidation and the concentration of free radicals in humans are normally maintained at a defined level by an antioxidant system that counteracts the processes of starting and developing free radical reactions. The action of pathogenic factors and the activation of endogenous mechanisms of free radical oxidation lead to a strain of the antioxidant defense mechanisms. In this regard, we were additionally presented the study of the level of catalase, which represents the first line of defense against free radicals.

Catalase is an enzyme of the class of oxidoreductases found in the cells of practically all aerobic organisms. Along with the degradation of hydrogen peroxide and thus the protection of the cell from its toxic effects, the enzyme catalyzes a number of metabolically significant protective reactions. Catalase activity in the blood is one of the prognostic tests of endotoxicosis severity in the human body [3].

It is known that the protein of the acute phase ferritin has antioxidant activity, it is a protein of the acute phase of inflammation, the main feature of which is a rapid and significant change in concentration as a result of disturbed homeostasis independent of the reason and location of the calling stimulus [3, 4].

Detection of pathogenetically significant metabolic disorders is not only theoretical, but also practical value, as it determines the direction of the search for effective means of correction of these disorders to optimize the treatment of infection caused by the stirpes of herpes.

\section{The aim of research}

Is to study the role of lipid peroxidation and antioxidant system in the pathogenesis of herpesvirus infection. 


\section{Materials and methods}

We studied the data of 80 patients with herpesvirus infection who received treatment in A.M. Nichoga Regional infectious clinical hospital in the city of Astrakhan. Molecular diagnostic methods (PCR) and detection of specific antibodies to herpes viruses (HSV-1, 2) in the diagnostic titer by three-phase enzyme immunoassay (EIA) were used to verify the diagnosis. The tested group consisted of 46 (57.5\%) boys and $34(42.5 \%)$ girls. The mean age of patients was $3.4 \pm 0.5$ years. The control group consisted of 30 healthy individuals. The research took into account all legislative and ethical requirements.

The object of the laboratory analysis were blood samples of patients with active form of herpesvirus infection. Blood for the preparation of serum was obtained by puncture of the qubital vein. The serum was separated from the blood cells by centrifugation at $3000 \mathrm{rpm}$ for 10 minutes in the first 2 hours after blood taking. The status of lipid peroxidation was determined by the level of malondialdehyde in the blood serum by the method of Jagi K. (1968) in modification of Kuzmenko D. I. and Laptev B. I. (1999) by reaction with thiobarbituric acid. For evaluation the antioxidant system, the serum ferritin level was determined by enzyme-linked immunosorbent assay using a set of reagents "Ferritin-ELISA-BEST" (Novosibirsk, Russia). Catalase activity was determined using the method of Korolyuk M. A. (1988).

Statistical data processing was carried out by standard methods of variation statistics using statistical indicators: Student's criterion and correlation coefficient. Mathematical data processing was carried out using Excel and for Windows.

\section{RESULTS AND DISCUSSION}

During the dynamic analysis, a significant increase in level of malondialdehyde in blood serum was found during the period of infection activity $(\mathrm{p}<0.001)$, which indicated the activation of the body's prooxidant system. During the period of clinical remission, in parallel with the positive dynamics of the disease, there is a significant decrease in malonic dialdehyde in blood serum $(\mathrm{p}<0.001)$ (Table 1$)$.

Analysis of the level of ferritin - a high-molecular iron-containing antioxidant protein involved in the metabolism and reallocation of iron in the body, revealed its significant increase in patients with herpesvirus infection by $71.3 \%$ in the main $(271.1 \pm 7.5)$ $\mathrm{ng} / \mathrm{ml}$ relative to the control group $(77.8 \pm 3.9) \mathrm{ng} / \mathrm{ml}$ $(\mathrm{p}<0,01)$. After the therapy in patients with herpesvirus infection, a decrease in the index relative to the baseline by $56.1 \%$ to $(118.9 \pm 7.6) \mathrm{ng} / \mathrm{ml}$ was revealed, which corresponded to the normal value interval (Table 1 ).
Table 1. Indicators of free radical oxidation in patients with herpesvirus infection

\begin{tabular}{|c|c|c|c|c|}
\hline The indicator & $\begin{array}{l}\text { Group of } \\
\text { surveyed }\end{array}$ & $\begin{array}{l}\text { Research } \\
\text { stage }\end{array}$ & $X \pm m$ & $p$ \\
\hline $\begin{array}{l}\text { Malonic } \\
\text { dialdehyde, } \\
\mathrm{mkmol} / \mathrm{l}\end{array}$ & $\begin{array}{l}\text { healthy } \\
\text { sick }\end{array}$ & $\begin{array}{l}\text { before treat- } \\
\text { ment after } \\
\text { treatment }\end{array}$ & $\begin{array}{l}0,73 \pm 0,072 \\
12,39 \pm 0,73 \\
0,77 \pm 0,29^{*}\end{array}$ & $\mathrm{p}<0,001$ \\
\hline $\begin{array}{l}\text { Catalase, } \\
\text { mkat/l }\end{array}$ & $\begin{array}{l}\text { healthy } \\
\text { sick }\end{array}$ & $\begin{array}{l}\text { before treat- } \\
\text { ment after } \\
\text { treatment }\end{array}$ & $\begin{array}{l}0,95 \pm 0,084 \\
0,023 \pm 0,008 \\
1,05 \pm 0,013^{*}\end{array}$ & $p<0,001$ \\
\hline $\begin{array}{l}\text { Ferritin, } \\
\mathrm{ng} / \mathrm{ml}\end{array}$ & $\begin{array}{l}\text { healthy } \\
\text { sick }\end{array}$ & $\begin{array}{l}\text { before treat- } \\
\text { ment after } \\
\text { treatment }\end{array}$ & $\begin{array}{l}77,8 \pm 3,9 \\
271,1 \pm 7,5^{*} \\
118,9 \pm 7,6^{*}\end{array}$ & $p<0,001$ \\
\hline
\end{tabular}

In the study of the activity of intracellular antioxidant catalase in patients with herpesvirus infection, there was a significant decrease before treatment $(p<0.001)$. After treatment patients with herpesvirus infection registered a significant increase in the level of catalase to normal values $(1.05 \pm 0.013) \mathrm{mkat} / \mathrm{l}$ $(\mathrm{p}<0.001)$ (Table 1).

Thus, in the dynamics of the disease in patients with herpesvirus infection there are nonspecific metabolic disorders in the form of activation of the processes of lipoperoxidation, increased acute-phase blood protein-ferritin and decreased activity of catalase.

The first time we found changes in metabolism allow us to deepen the understanding of the pathogenesis of herpesvirus infection, which contributes to solve clinical problems of medical science, especially the improvement of diagnosis and treatment.

\section{REFERENCES}

1. Avdeeva M.G., Shubich M.G. Pathogenetic mechanisms of systemic inflammatory response syndrome initiation / M.G. Avdeeva, M.G. Shubich // Clinical laboratory diagnostics. - 2003. - №6. - p. 3-10.

2. Kelina N.Yu., Vasilkov V.G., Bezruchko N.V. Methodology of evidence-based biochemical evaluation of endotoxicosis development / N.Yu. Kelina, V.G. Vasilkov, N.V. Bezruchko // Herald intensive care. - 2002. - № 4. - p. 13-17.

3. RyazANTSEva L.T. Antioxidant enzymes: structural and functional properties and role in the regulation of metabolic processes / L.T. Ryazantseva / / Bulletin of the Voronezh State tech. un-ty. - 2011. - V.7. - № 2. - P. 126-129.

4. Chesnokova N.P., Ponukalina E.V., Bizenkova M.N. General characteristics of sources of formation of free radicals and antioxidant systems / N.P. Chesnokova, E.V. Ponukalina, M.N. Bizenkova // Successes of modern natural science. - 2006. - № 7. - p. 37-41. 